\title{
How the Students Use Ethical Theories to Name Their "Most Ethical” Person Awards
}

\author{
R. Wayne Counts, John-Paul Pitre, Carol Sullivan \\ University of Texas of the Permian Basin, Texas, USA
}

\begin{abstract}
When several scandals damaged the USA business environment, ethics education became a mandate for students in several states. Ethical theories were integrated into the business curriculum and the students are expected to apply these theories to the real world. The purpose of this research is to provide information related to the students' applications as they named their "most ethical” person and communicated the reasoning behind their selection.
\end{abstract}

Keywords: ethics, role models

\section{Introduction}

When the business environment was damaged by several scandals, accounting ethics education became a mandate for the students in several states. Utilitarianism, ethical egoism, and deontology are three examples of the theories that students experience and our hope is that they can apply what they are learning in ethics to people in the business environment. The purpose of this research is to provide information related to the students' choices of "most ethical” person after learning ethics in their auditing or state mandated ethics courses. The courses discuss items such as rules vs. principles, personal responsibilities vs. fiduciary responsibilities, and how culture influences behavior taught in the courses. As a culminating experience, students are asked to name their "most ethical" person and provide the reasoning behind their choice. As the choices are grouped together, it makes for great discussion and debate as to what is most important when applying the ethical theories to the selection process of real people. The purpose of this research is also to provide a research background for business ethics and share some of the students' selections as well as their reasoning for their selections.

\section{Research Background and Literature Review}

Callahan's (1988) research was motivated by the increase in a variety of ethics courses, yet these courses did not meet the needs of students preparing for professional life. This research focused on particular professions and integrated ethical questions with real-world cases. Students could use both knowledge acquisition and application to help develop their own ethical theories.

Trevino and Nelson's (2014) research was a response to the business stories describing ethical meltdowns and corporate misdeeds. It relates to management of ethical conduct. It helps students understand that management of ethical dilemmas may one day be a part of their work life.

R. Wayne Counts, Associate Professor, Accounting, University of Texas of the Permian Basin. Email: Counts_R@utpb.edu. John-Paul Pitre, Graduate Student, Accounting, University of Texas of the Permian Basin.

Carol Sullivan, Associate Professor, Accounting, University of Texas of the Permian Basin. 
Lopez, Rechner, and Olson-Buchanan (2005) provided similar research findings by examining the "forces" that shape ethical perceptions and considered the effects of education, culture, and other demographic factors that influence ethical perceptions. This study was a response to Kmart, Tyco, and Aldephia scandals and they found significant ethical perception differences for both intra-national culture and area of specialization within business. Knights and O'Leary (2005) also studied some of the same scandals and found that a significant obstacle to ethical leadership was preoccupation with self and success, both material and symbolic success. They proposed a return to Aristotelian virtue ethics, whereby virtues promotes community values and solidarity rather than individualism.

Ferrell, Fraedrich, and Ferrill (2013) helped students understand the complex environment of ethical decision-making. Every person has a very unique set of personal principles and values; then the organization has its own set of values, rules, and organizational ethical culture. This research allows students to see the roles and responsibilities that they will deal with in business. Hoffman, Frederick, and Schwartz (2014) extended the theories by trying to create a systematic approach to resolving ethical issues. By learning more moral philosophy, students hope to have better careers. Zhu, Trevino, and Zheng (2016) extended the Ferrell et al.'s (2013) research by studying the association between the ethical leaders' characteristics and potential influence of ethical leadership on followers' ethical characteristics. They found that there was a significant correlation between the two sets of characteristics. This study helped student understand that people will be watching them as they lead and helped them also start looking at the ethical characteristics of current business leaders.

Cheffers and Pakaluk (2005) provided some of the leading research related to accounting ethics and that is a bit of the focus of the current research since accounting students and accounting courses were involved. It called for a renewed sense of principles-based accounting and professionalism after the Enron and Worldcom scandals. The research helped students understand the idea of a virtue-based approach to ethics as well as traditional approaches such as utilitarianism and Kantianism.

Lee and Cheng (2011) explored the characteristics of ethical leaders in the public relations industry. The three salient characteristics found in their "ideal leader" were personal ethics, interpersonal behaviors, and articulation of ethical standards. The interesting aspect of this research is that it helped students understand that personal ethics are at the forefront of ethical leaders' characteristics. Frisch and Huppenbauer (2014) extended the Lee and Cheng's (2011) study by investigating what specific behaviors do ethical leaders show. They provided information related to ethics based on the stakeholders' approach: employees, shareholders, customers, suppliers, and society as a whole. This research helped students understand the complexity associated with ethical issues as many people can be involved with one issue. Marsh (2013) summarized the findings of a qualitative research study related to business executives' perceptions of ethical leadership. Recollections of critical incidences were shared and the business executives explained how the ethical issue in the incident helped form their values. The two research questions were as follows: (1) what aspects of ethical leadership are valued by those who consider themselves as ethical leaders? and (2) in what way do life experiences of those who perceive themselves to be ethical leaders inform the understanding of the process of ethical leadership development? The research findings found that concepts such as virtue ethics, mindfulness, authenticity, and sustainment were important. 
Finally, Wang, Feng, and Lawton (2017) researched the ethical theoretical framework and employed a multi-source survey completed by 264 Chinese firms. They tested the basic idea of whether high ethical standards resulted in better financial and social performance. The study found that both leader humane orientation and leader responsibility and sustainability orientation had positive influences on both firm financial and social performance. The findings of this study have practical implications for encouraging students to have high ethical standards.

\section{Students' “Most Ethical” Person Selections}

After studying business and accounting ethics in both auditing and accounting ethics courses, students were asked to name their "most ethical" person and state their reasoning behind this selection as part of the class requirements. A subset of responses are as follows:

(1) The most ethical business person in my opinion is my sister, Sue Bement. She is a CPA in Tulsa, Oklahoma. Sue has always been what I considered a "goody-two-shoes" growing up but I now see her as having a strong moral compass. She is very fair-minded and always does what is right regardless of how it will affect her personally. She just left a high-paying career with a small oil and gas company because she did not feel comfortable with the direction it was starting to go under new management. Sue is my younger sister but I often look to her as my mentor in the field of accounting;

(2) My "most ethical" business leader is my first boss at my first job. His name is Rocky Hale and he is the owner and manager at his Tex-Mex restaurant in Big Spring, Texas. I worked there for five years and at that time I was able to see first-hand how this man proved to, not only his employees, but also his customers the great ethics and leadership that he possessed. The reason why I chose him is because being an owner of a restaurant is not cheap or easy, but while working with him, he would go the extra mile to make sure his customers were happy and satisfied. If an order was wrong or missing something, he would correct it, apologize, and guarantee their money back or replace the meal for free. Many would consider this absurd, but I consider this a great business leader, there are not many owners who would go to this extreme and lose profit/merchandise for customers so easily. Another reason why I chose him to be the "most ethical" is because being the owner of a company and your wife being the co-owner, could possibly cause checks and balance to be a problem. Yet, he continues to hire an accountant and have outside auditors to come monitor his merchandise/taxes. It is not always easy to run a business, but this man is doing a great job. If you ask the people of Big Spring, they can attest if this man is a great "most ethical' business leader in that town;

(3) The most ethical business leader I know is Dick Saulsbury. He started his business in his back yard on Golder Ave. back in the 1960s. The company employees are over 3,000 and is Odessa's largest non-public company. My husband went to school with Dick’s son Mark, and Mark is our neighbor. Saulsbury has donated money for several scholarships and a building for Odessa College. He is involved in his community. Dick Saulsbury has not forgotten where his roots started, and he tries to help people in need. He still acts like he did back when Saulsbury Electric was in his back yard;

(4) The person I view as the most ethical leader is Wesley Bownds, President of the Permian Basin market for Frost Bank. I worked for Wesley for more than seven years and always admired how he treated and interacted with people. I think good ethical leaders need to model ethical conduct to their employees. I believe Wesley did this by demonstrating that doing right by employees and customers was more important than the bottom line; 
(5) Melinda Gates is the co-chair of the Bill and Melinda Gates Foundation. It has been Bill's and Melinda's mission to give away 95\% of their wealth. Through her work with the foundation, Melinda has helped empower thousands of women and girls around the world. In 2012, Melinda pledged $\$ 560$ million toward improving access to contraception for women in third-world countries. She has also increased her focus of gender equality as a path to meaningful change. Furthermore, in 2015 Melinda announced that her employees would receive up to a year of paid leave after birth of a child or adoption. Lastly, through the Gates Millennium Scholars Program, she has helped fund more than 20,000 students' education. Melinda encompasses the true definition of an ethical business leader. Someone who values equality of men and woman, human rights, and has a concern for health and safety;

(6) My most ethical business leader is Jeff Weiner who is the CEO of LinkedIn. LinkedIn allows for business professionals to meet like-minded people and connect with them on a professional level. He has been able to keep LinkedIn as an employment-based platform, potentially helping users get connected to the right career. This platform, by Weiner, creates a relationship built on trust because the connections must be introduced by a mutual connection;

(7) The person I believe to be the "most ethical" business leader is Hubert Joly. He is the current CEO for Best Buy, a company I just most recently worked for. During the time I worked there he stressed the importance of being honest with customers and management so we could better develop our company. He developed an idea called "Renew Blue" in which the premise was no blue shirt goes untrained and no customer goes unserved. This shows me how ethical he is because instead of coming into Best Buy and making shady deals and cuts in order to turn the customer around he invested into its people and made sure people knew what we were doing to turn the company around. He was very upfront and honest with us in all business emails, memos, and meetings, making sure we knew exactly where the company stood instead of lying to us. He also always wore a Best Buy blue polo like everyone else to emphasize that we were all in this together as a team;

(8) My "most ethical" business leader is Indra Nooyl, CEO of PepsiCo. Indra lives by moral codes. She feels that every corporation owes society care. She leads in a way that respects the community and the company. Indra also led PepsiCo’s Performance with Purpose. On the PepsiCo’s Performance with Purpose webpage, Indra states, "Performance with Purpose represents our fundamental belief that in the 21st century, a good company must also be a good citizen";

(9) I believe Dan Arnold, former owner of Highland Concrete, is my most ethical business leader. He remained as the President of Shared Services when Highland Concrete was bought by a private equity firm, which his duties included management of the transportation department and human resources. Dan was very approachable and down to earth. If ever there was an issue, Dan would sit down with you and explain all the issues and possible outcomes, he was very honest. Good news or bad news, it was what it was, and he wasn't ashamed, afraid, or embarrassed to discuss it with the employees;

(10) Michael S. Hobbs is a very ethical business owner. He took over the business in 2015, when his father passed away. After working for other machine shops in the area, he stated working for his dad full time in 1990. I have worked here for over a year, and I consider his actions in business and in his personal life to be very ethical. He never asks his employees to do anything that he wouldn't do himself. If one employee has to work late or work weekends he works right alongside them. If he takes a bonus, he gives every employee a bonus. Since I have been here for two fiscal year ends, he has always paid his taxes without trying to short the government in anyway. He doesn't try and make any accounting changes at all. If there is a question, he just asks me why it was done that way. 
It is interesting to note both the diversity of individuals selected and the reasons described for the students' selection. Some of the people selected were very local, whereby the students had a first-hand, long-time observation of the person's ethical leadership while others were more high profile leaders of major corporations. It is interesting to note that Melinda Gates was selected twice while her husband, Bill Gates - founder of Microsoft, was not selected in the students' responses. This finding does not mean that Bill Gates is not considered an ethical leader, but it does reflect a diversity of students' perceptions with a famous couple. Finally, it is quite interesting how ethical dilemmas were mentioned in several students' reasoning and how much the students admired high ethical standards being used to resolve the ethical dilemmas. There also seems to be a positive relationship between the people selected and firm financial and social performance in this sample.

\section{Concluding Remarks}

This research study examined previous research related to both accounting ethics and business ethics. Then students' responses to their questions related to both their "most ethical" leaders and their reasoning behind the selections were offered as a way to show how students gain knowledge related to ethical theories and then applied this knowledge to real-world people and real-world companies in the business environment. Implications of this research involve ethics education, student perceptions, and society as a whole.

\section{References}

Callahan, J. (1988). Ethical issues in professional life. New York, NY: Oxford Press.

Cheffers, M., \& Pakaluk, M. (2005). Understanding accounting ethics: Principles, professionalism, pride. Massachusetts, MA: Allen David Press.

Ferrell, O., Fraedrich, J., \& Ferrill, L. (2013). Business ethics: Ethical decision making and cases. Ohio, USA: Southwestern Publishing.

Frisch, C., \& Huppenbauer, M. (2014). New insights into ethical leadership: A qualitative investigation of the experiences of executive ethical leaders. Journal of Business Ethics, 123(23), 23-43.

Hoffman, M., Frederick, R., \& Schwartz, M. (2014). Business ethics: Readings and cases in corporate morality. New York, NY: John Wiley \& Sons.

Knights, D., \& O’Leary, M. (2005). Reflecting on corporate scandals: The failure of ethical leadership. Business Ethics: A European Review, 14(4), 359-366.

Lee, S., \& Cheng, L. (2011). Characteristics and dimensions of ethical leadership in public relations. Journal of Public Relations Research, 23(1), 46-74.

Lopez, Y., Rechner, P., \& Olson-Buchanan, J. (2005). Shaping ethical perceptions: An empirical assessment of the influence of business education, culture, and demographic factors. Journal of Business Ethics, 60(34), 341-358.

Marsh, C. (2013). Business executives’ perceptions of ethical leadership and its development. Journal of Business Ethics, 114(3), 565-582.

Trevino, L., \& Nelson, K. (2014). Managing business ethics: Straight talk about how to do it right. New York, NY: John Wiley \& Sons.

Wang, D., Feng, T., \& Lawton, A. (2017). Linking ethical leadership with firm performance: A multi-dimensional perspective. Journal of Business Ethics, 145(1), 95-109.

Zhu, W., Trevino, L., \& Zheng, X. (2016). Ethical leaders and their followers: The transmission of moral identity and moral attentiveness. Business Ethics Quarterly, 26(1), 95-115. 